TAPROBANICA, ISSN 1800-427X. August, 2014. Vol. 06, No. 02: pp. 72-75, pls. 1, 2.

(C) Research Center for Climate Change, University of Indonesia, Depok, Indonesia \& Taprobanica Private Limited, Homagama, Sri Lanka http://www.sljol.info/index.php/tapro

\title{
A NEW SPECIES OF Sonerila (MELASTOMATACEAE) FROM THE WESTERN GHATS OF KERALA, INDIA
} ${ }^{1}$ Plant Systematics \& Evolutionary Science Division, Jawaharlal Nehru Tropical Botanic Garden and Research
Institute, Palode, Karimancode P.O., Thiruvananthapuram District, Kerala 695562, India.

\begin{abstract}
A new species, Sonerila keralensis, from the Western Ghats of Kerala is described and illustrated. It is allied to $S$. rheedei differing by having a tuberous root stock, three to seven flowers, and petals with sparsely glandular-hairy margins.
\end{abstract}

Key words: taxonomy, Sonerila keralensis, Thirunelli, Melastomataceae, tropical Asia, endemic

\section{Introduction}

Members of Sonerila Roxb. (Melastomataceae Juss.; Sonerileae Triana) are ephemeral herb characterised by scorpioid cymes, trimerous flowers, and 3-celled inferior ovaries. They are seen commonly during monsoon in rock crevices and on stream banks of montane region. The genus has about 175 species distributed mainly in tropical Asia from India Sri Lanka to Indo-Pacific (Cellinese, 1977; Lundin \& Nordenstam, 2009).

In India, as per the latest assessment, the genus is represented by 48 species and four varieties (Clarke, 1879; Fischer, 1932, 1935, 1938; Nayar, 1969, 1976, 1987; Giri \& Nayar, 1984, 1985a-b, 1986 a-c, 1987a-b; Prakash \& Mehrotra, 1988; Gopalan \& Henry, 1989; Giri et al., 1992; Ravikumar, 1999; Murugan \&
Manickam, 2002; Josephine et al., 2003; Lundin \& Nordenstam (1.c); Murugesan \& Balasubramaniam, 2011; Ratheesh Narayanan et al., 2013; Sunil et al., 2014). Thirty-two species, including 18 endemics and 10 threatened, are known to occur in Western Ghats.

During the systematic inventory of the genus Sonerila of Western Ghats, an interesting specimen was collected from Thirunelli, Wayanad District, Kerala, at an altitude $\sim 1000$ $\mathrm{m}$. The specimen is similar to $S$. rheedei Wall. ex Wight \& Arn. We observed the plant over three consecutive growing seasons (20092011) and found that the characters attributed to this population are stable. Hence it is here described and illustrated as a new species. 


\section{Taxonomy}

Sonerila keralensis Deepthikum. and Pandur. sp. nov.

(Figs. 1, 2; Table 1)

Type: India, Kerala State, Wayanad District, Thirunelli, $1000 \mathrm{~m}$ elevation, 30 Jun 2009, K.P. Deepthikumary \& A.G. Pandurangan 60590 (holotype: TBGT; isotype: MH).

Diagnosis: Allied to Sonerila rheedei differing by having a tuberous root stock, an erect, apically branched stem, 3-7 flowers per inflorescence, sparsely glandular-hairy petal margins with a glabrous midrib, non-beaked anthers, and a capsule with a few glandular hairs.

Description: Herbs, erect, to $30 \mathrm{~cm}$ high; root stock tuberous; stem thin, cylindrical, green, pubescent, branching at apex. Leaves opposite, ovate or ovate-lanceolate, $3-9 \times 2.5-4.5 \mathrm{~cm}$, membranous, green, densely glandular hairy on both surface, acute or rarely rounded basally, minutely serrate marginally, obtuse apically; nerves 4-5 pairs; petioles $1.5-4 \mathrm{~cm}$ long, channelled above, glandular hairy. Inflorescences scorpioid cymes, terminal or axillary, 3-7-flowered; peduncles 4-10 cm long, translucent, pale green, pubescent; pedicels ca. $5 \mathrm{~mm}$ long, pink, hairy. Calyx tube campanulate, ca. $5.5 \mathrm{~mm}$ long; lobes 3, pink, sparsely glandular. Petals 3 , ovate-acuminate, ca $5 \times 4 \mathrm{~mm}$, rosy pink, sparsely glandular hairy marginally; midrib glabrous. Stamens 3; filaments ca. $4 \mathrm{~mm}$ long; anthers lanceolate, inflated basally, attenuate apically, not beaked, dehiscence by apical pores. Ovary 3-celled; style slender; stigma capitate. Capsules 5-10 $\mathrm{mm}$ long, cup shaped with a white rim at apex, sparesly glandular hairy.

\section{Flowering and Fruiting: August-October.}

Etymology: The specific epithet refers to the Kerala state where this species is found.

Table 1: Comparison of the new species with Sonerila sahyadrica and S. rheedei

\begin{tabular}{|c|c|c|}
\hline S. keralensis sp. nov. & S. sahyadrica & S. rheedei \\
\hline $\begin{array}{l}\text { Root stock tuberous with erect stem } \\
\text { up to } 25 \mathrm{~cm} \text {, branched apically }\end{array}$ & $\begin{array}{l}\text { Root stock tuberous with } \\
\text { short stem up to } 2 \mathrm{~cm} \text { long, } \\
\text { branched apically }\end{array}$ & $\begin{array}{l}\text { Root stock not tuberous with } \\
\text { procumbent stem, unbranched } \\
\text { apically }\end{array}$ \\
\hline 3-7 flowers per inflorescence & $\begin{array}{l}\text { 5-10 flowers per } \\
\text { inflorescence }\end{array}$ & 5-16 flowers per inflorescence \\
\hline $\begin{array}{l}\text { Petals sparsely glandular-hairy } \\
\text { marginally; midrib glabrous }\end{array}$ & $\begin{array}{c}\text { Petals glandular-hairy } \\
\text { marginally; midrib glandular- } \\
\text { hairy }\end{array}$ & $\begin{array}{l}\text { Petals glandular-hairy marginally; } \\
\text { midrib glandular-hairy only dorsally }\end{array}$ \\
\hline Anthers not beaked & Anthers not beaked & Anthers long-beaked \\
\hline $\begin{array}{l}\text { Capsule 5-10 mm long, sparsely } \\
\text { glandular-hairy }\end{array}$ & $\begin{array}{l}\text { Capsule } 2.5-4 \text { mm long, } \\
\text { glandular hairy }\end{array}$ & $\begin{array}{c}\text { Capsule 2-3.5 mm long, glandular- } \\
\text { hairy }\end{array}$ \\
\hline
\end{tabular}

Habitat and Ecology: Sonerila keralensis grows in moist rock crevices in the spray zone of waterfalls and along stream banks in semievergreen and evergreen forests at an altitude of $150 \mathrm{~m}$ to $1000 \mathrm{~m}$ in association with Begonia crenata Dryand., Biophytum candolleanum Wight, Impatiens scapiflora B. Heyne ex Roxb., I. diversifolia B. Heyne ex Wight \& Arn., I. goughii Wight., I. minor (DC.) Bennet, etc.

Distribution: India: Western Ghats located within the boundary of Wayanad, Idukki, and Thrissur districts, Kerala State.
Conservation status: The species was collected by several workers from different parts of Western Ghats from $150-1000 \mathrm{~m}$ above sea level and identified as Sonerila rheedei. The extent of occurrence, by taking into account all known locations, comes to $20,000 \mathrm{~km}^{2}$, the habitable sites within this range determining population size. Therefore, at present the species can be treated as vulnerable under the IUCN guidelines (IUCN 2001, 2010).

Specimens examined: Kerala State, Wayanad Dist., Thirunelli, 1000 m. 30 Jun 2009, K.P. Deepthikumary \& A.G. Pandurangan 60590 
(type material, MH, TBGT); Idukki Dist., Walara, 16 Sep 1992, A.E. Shanavaskhan 12824 (TBGT); Thrissur Dist., Athirappilly, $\sim 150$ m, 14 Sep 1996, A.G. Pandurangan \& G. Rajkumar 30788 and A.G. Pandurangan \& G. Rajkumar 30789 (TBGT).

Remarks: Giri \& Nayar (1984) studied members of the Sonerila rheedei complex and proposed S. sahyadrica G.S. Giri \& M.P. Nayar based on its tuberous root stock and short stems. Our new species also has a tuberous root stock but with long stem. Sonerila rheedei does not have a tuberous root stock. The differences between these species are summarized above (Table 1).

The species name "rheedii" was proposed by Wallich in 1831 (no. 4096) but his name was not validly published. The name was subsequently validated by Wight \& Arnott as $S$. rheedei honoring H.A. Rheede tot Draakestein (1637-1691) (Wight \& Arn., Prodr. 1: 321. 1834) and this is the correct orthography as per Art. 60.7 of the International Code for Nomenclature (McNeill et al. 2012). Subsequent Indian botanists, unfortunately, retained "S. rheedii" without referring the original publication. Therefore, the correct name of the taxon is: Sonerila rheedei Wall. ex Wight \& Arn.

\section{Acknowledgements}

The authors are grateful to the Director (JNTBGRI) for the facilities and constant encouragement. We are thankful to E.S. Santhosh Kumar (JNTBGRI) for technical assistance.

\section{Literature cited}

Wight, R. and G. A. W.Arnott, 1834. Prodromus Florae Peninsula Indiae Orientalis: Containing Abridged Descriptions of the Plants found in the Peninsula of British India, Arranged According to the Natural System, Vol. 1. Parbury, Allen \& Co., London.

Cellinese, N., 1977. A new Sonerila (Melastomataceae) from central Kalimantan, Borneo. Novon, 7: 103-105.

Clarke, C. B., 1879. Sonerila. In: J. D. Hooker (ed.), Flora of British India, Vol. 2. Reeve \& Co., London: 792.
Fischer, C. E. C., 1932. Plants new to Assam IV. Bulletin of Miscellaneous Information, 1932: 198-203.

Fischer, C. E. C., 1935. New or little known plants from South India: VI. Bulletin of Miscellaneous Information, 1935: 157-160.

Fischer, C. E. C., 1938. New or little known plants from South India: VIII. Bulletin of Miscellaneous Information, 1938: 32-37.

Giri, G. S. and M. P. Nayar, 1984. New species and notes on two species of Sonerila Roxb. (Melastomataceae ) from South India. Bulletin of the Botanical Survey of India, 26: 174-180.

Giri, G. S. and M. P. Nayar, 1985a. A new species of Sonerila Roxb. (Melastomataceae) from southern India. Bulletin of the Botanical Survey of India, 27: 86-89.

Giri, G. S. and M. P. Nayar, 1985b. A new species of Sonerila Roxb. (Melastomataceae) from India. Blumea, 31: 235-237.

Giri, G. S. and M. P. Nayar, 1986a. A new species of Sonerila Roxb. (Melastomataceae) from India. Journal of Japanese Botany, 61: 344348.

Giri, G. S. and M. P. Nayar, 1986b. A new species and notes on two species of Sonerila Roxb. (Melastomataceae) from South India. Bulletin of the Botanical Survey of India, 26: 174-180.

Giri, G. S. and M. P. Nayar, 1986c. A new variety of Sonerila sadasivanii Nayar (Melastomataceae) from southern India. Bulletin of the Botanical Survey of India, 26: 189-190.

Giri, G. S. and M. P. Nayar, 1987a. A new species of Sonerila Roxb. (Melastomataceae) from southern India. Bulletin of the Botanical Survey of India, 27: 86-89.

Giri, G. S. and M. P. Nayar, 1987b. A new variety of Sonerila elegans Wight (Melastomataceae) from Kerala, India. Bulletin of the Botanical Survey of India, 27: 72-74.

Giri, G. S., A. Pramanik, and H. J. Chowdhery, 1992. A new species of Sonerila Roxb. (Melastomataceae) from Arunachal Pradesh, India. Indian Journal of Forestry, 15: 95-96. 
Gopalan, R. and A. N. Henry, 1989. A new species of Sonerila Roxb. (Melastomataceae) from southern India. Journal of the Bombay Natural History Society, 86: 82-83.

IUCN, 2001. IUCN Red List Categories and Criteria: Version 3.1. IUCN Species Survival Commission. IUCN, Gland \& Cambridge.

IUCN, 2010. Standards and Petitions Subcommittee. Guidelines for using the IUCN Red List Categories and Criteria: version 8. IUCN, Gland \& Cambridge.

Josephine, M. M., V. S. Manickam, C. Murugan, V. Sundaresan, and G. J. John, 2003. Sonerila longipetiolata Manickam. A new species of Melastomataceae from Tamil Nadu, India. Journal of the Bombay Natural History Society, 100: 81-83.

Lundin, R. and B. Nordenstam, 2009. Two new species of Sonerila (Melastomataceae) from South India. Novon, 19: 76-79.

Murugesan, C. and V. S. Manickam, 2002. New species of Memecylon and Sonerila (Melastomataceae) from southern Western Ghats of India. Journal of Economic and Taxonomic Botany, 25: 509-513.

Murugesan, M. and V. Balasubramaniam, 2011. A new species of Sonerila (Melastomataceae) from the Western Ghats, India. Taprobanica, 3: 93-95.

Nayar, M. P., 1969. A new species of Sonerila Roxb. (Melastomataceae) from South India. Proceedings of the Indian Academy of Science, 69: 256-258.

Nayar M. P., 1976. A new species of Sonerila (Melastomataceae) from Kerala, S. India. Journal of the Bombay Natural History Society, 7: 632633.

Nayar M. P., 1987. Hot spot of Endemic Plants of India, Nepal \& Bhutan. Tropical Botanic Garden \& Research Institute, Palode, Trivandrum: 252.

Nayar, T. S., A. Raziabeegam, N. Mohanan, and G. Rajkumar, 2006. Flowering Plants of Kerala, A Hand Book. Tropical Botanic Garden \& Research Institute, Palode, Trivandrum: 1069.

McNeill, J., F. R. Barrie, W. R. Buck, V. Demoulin, W. Greuter, D. Hawksworth, P. S.Herendeen, S. Knapp, K. Marhold, J. Prado, W.
F. Prud-Homme van Reine, G. F. Smith, J. H. Wiersema, and N. J. Turland, 2012. International Code of Nomenclature for algae, fungi and plants (Melbourne Code). Regnum Vegetabile, 154: 1240 .

Prakash, V. and B. N. Mehrotra, 1988. A new species of Sonerila Roxb. (Melastomataceae) from Meghalaya, India. Candollea, 43: 143-145.

Ratheesh Narayanan, M. K., V. Mini, T. Shaju, K. A. Sujana, J. P. Joseph, A. H. Alfarhan, and M. Sivadasan, 2013. A new species of Sonerila Roxb. (Melastomataceae) from Kerala, India. Phytotaxa, 110: 55-60.

Ravikumar, K., 1999. Novelties from High Wavy Mountains, southern Western Ghats, Theni District, Tamil Nadu, India. Rheedea, 9: 55-75.

Sunil, C. N., V. V. Naveen Kumar, and T. S. Rajeev, 2014. Sonerila sreenarayaniana (Melastomataceae), a new species from Kerala, India. International Journal of Advanced Research, 2: 701-704.

Wallich, N., 1828-1849. A Numerical List of Dried Specimens of Plants, in the East India Companys [sic] Museum Collected under the Superintendence of Dr. Wallich of the Company's Botanic Garden at Calcutta, 10 parts. Lithograph, London. 


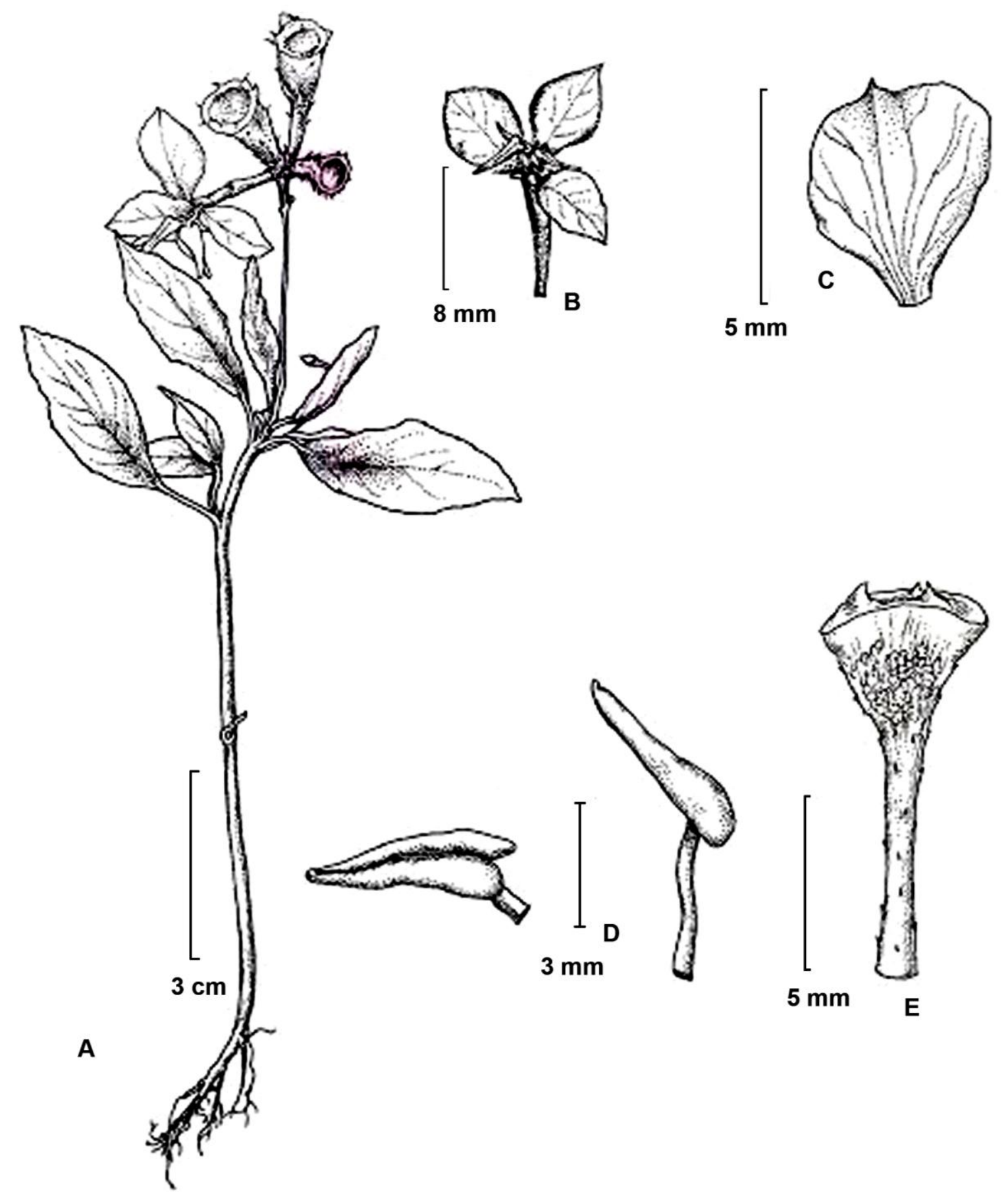

Figure 1: Sonerila keralensis sp. nov. A, habit; B, flower; C, petal; D, stamens; E, capsule. 


\section{PLATE 2}
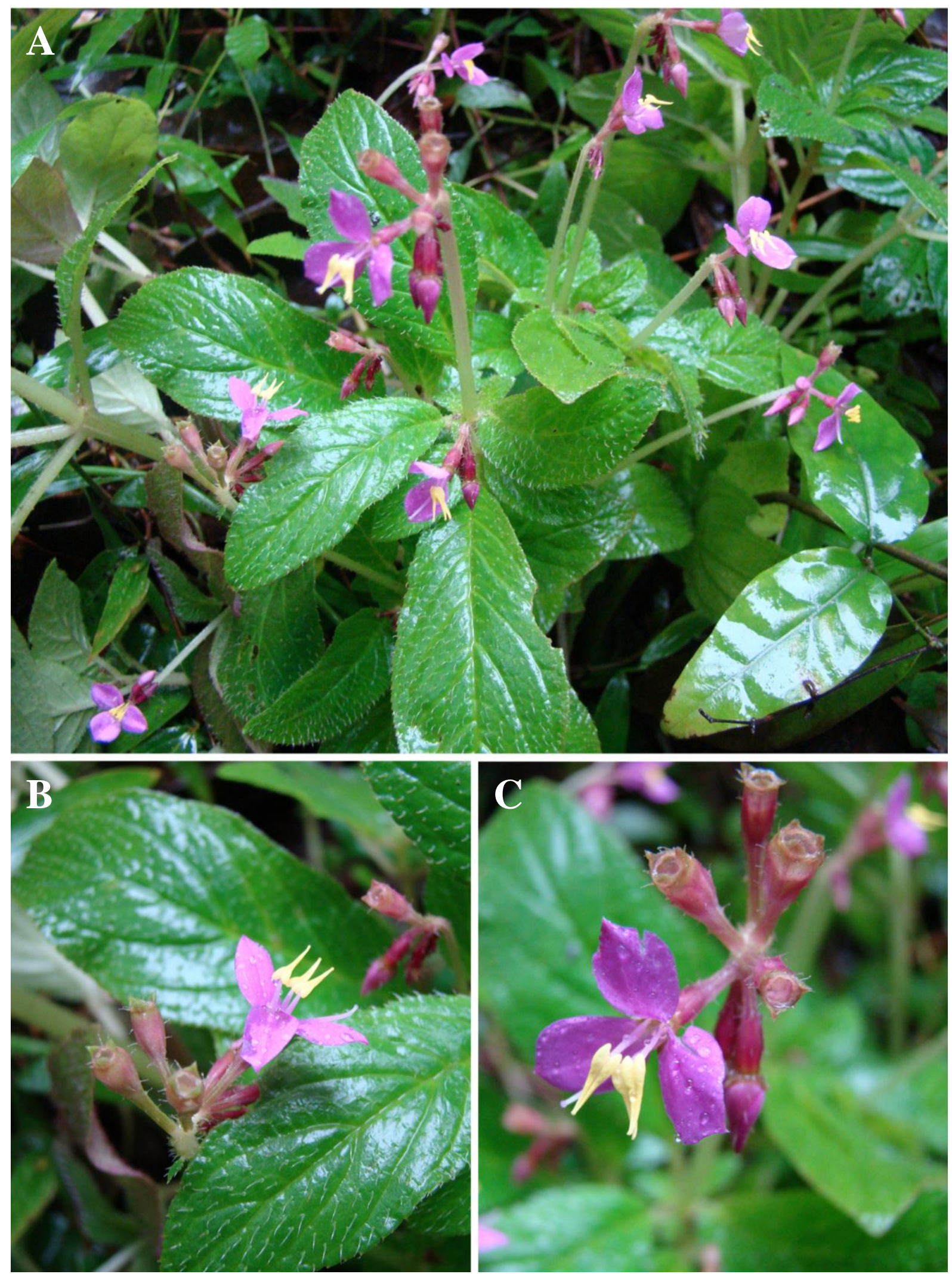

Figure 2: Sonerila keralensis sp. nov. A, View of habit; B, detail of a flower; C, Inflorescence showing two buds, a flower and four capsules. 